Joanna Maria Mędrzecka

Adwokat, Sopot

joanna.medrzecka@adwokatura.home.pl

\title{
Kilka uwag co do zasadności utrzymywania w polskim systemie prawnym instytucji przymusowej restrukturyzacji spółdzielczych kas oszczędnościowo-kredytowych
}

http://dx.doi.org/10.12775/SIT.2020.027

Obecnie w polskim systemie prawnym w odniesieniu do banków, w tym banków spółdzielczych, a także do spółdzielczych kas oszczędnościowo-kredytowych funkcjonują dwie odrębne i bardzo rozbudowane instytucje prawne, związane $z$ ingerencją nadzoru publicznego w przypadku zakłóceń stabilności banków lub kas, w postaci restrukturyzacji banków i kas (prowadzonej zasadniczo przez Komisję Nadzoru Finansowego) oraz przymusowej restrukturyzacji takich podmiotów (której prowadzenie powierzono Bankowemu Funduszowi Gwarancyjnemu, przy zachowaniu opiniodawczej roli Komisji Nadzoru Finansowego) ${ }^{1}$. W przypadku obu tych instytucji

${ }^{1}$ Szerzej na temat instrumentów przymusowej restrukturyzacji stosowanych przez Bankowy Fundusz Gwarancyjny zob. W. Piłat, Nowe procedury przymusowej restrukturyzacji i uporzadkowanej likwidacji instytucji bankowych (resolution regime), „Doradca Restrukturyzacyjny” 2016, nr 3, s. 128-146. 
możliwe jest wsparcie finansowe Bankowego Funduszu Gwarancyjnego, w szczególności odpowiednio $z$ funduszu przymusowej restrukturyzacji banków, $z$ funduszu przymusowej restrukturyzacji kas, z funduszu restrukturyzacji banków spółdzielczych (przy zachowaniu pewnych możliwości przenoszenia środków między poszczególnymi funduszami istniejącymi w Bankowym Funduszu Gwarancyjnym). Oprócz tego oczywiście możliwa jest także dobrowolna restrukturyzacja banku lub kasy $z$ wykorzystaniem instytucji prawnych łączenia się spółek akcyjnych na podstawie przepisów Kodeku spółek handlowych lub łączenia się spółdzielni na podstawie przepisów Prawa spółdzielczego, za zgodą Komisji Nadzoru Finansowego ${ }^{2}$. Pojęcie restrukturyzacji banków i restrukturyzacji kas występuje w przepisach Ustawy z dnia 10 czerwca 2016 r. o Bankowym Funduszu Gwarancyjnym, systemie gwarantowania depozytów oraz przymusowej restrukturyzacji ${ }^{3}$, choć instrumenty restrukturyzacji, zwane w języku prawniczym także instrumentami nadzorczymi, uregulowane są odpowiednio w Ustawie $z$ dnia 29 sierpnia 1997 r. - Prawo bankowe ${ }^{4}$ i w Ustawie $z$ dnia 5 listopada 2009 r. o spółdzielczych kasach oszczędnościowo-kredytowych ${ }^{5}$. Instrumenty przymusowej restrukturyzacji nazwane są w ten sposób i uregulowane w ustawie o BFG.

Minęły trzy lata obowiązywania Ustawy z dnia 10 czerwca 2016 r. o Bankowym Funduszu Gwarancyjnym, systemie gwarantowania depozytów oraz przymusowej restrukturyzacji, która została uchwalona w ramach transformacji do polskiego systemu prawnego postanowień Dyrektywy ustanawiającej ramy na potrzeby prowa-

2 Za zgodą Komisji Nadzoru Finansowego na podstawie przepisów Kodeksu spółek handlowych w przypadku banków w formie spółki akcyjnej oraz na podstawie przepisów prawa spółdzielczego w przypadku banków spółdzielczych i kas możliwy jest także podział banku lub kasy, jednakże taki sposób przekształcenia organizacyjnego nie jest wykorzystywany w praktyce w przypadku kas.

${ }^{3}$ Tekst jednolity: Dz.U. z 2020 r. poz. 842, dalej: ustawa o BFG.

${ }^{4}$ Tekst jednolity: Dz.U. z 2019 r. poz. 2357, dalej: Prawo bankowe. Zob. też M. Torończak, Przejęcie banku - zagadnienia wybrane, „Monitor Prawa Bankowego" 2019, nr 4, s. 64-80; Dz.U. z 2019 r. poz. 2357 ze zm.

5 Tekst jednolity Dz.U. z 2019 r. poz. 2412, dalej: ustawa o SKOK. 
dzenia działań naprawczych oraz restrukturyzacji w odniesieniu do instytucji kredytowych i firm inwestycyjnych, przyjętej przez Parlament Europejski w kwietniu 2014 r. i opublikowanej w Dzienniku Urzędowym Unii Europejskiej w dniu 12 czerwca 2014 r. jako dyrektywa 2014/59/UE (zwana BRRD albo dyrektywa BRR), która była następnie uzupełniana i nowelizowana ${ }^{6}$.

Dyrektywa ta nakładała na państwa członkowskie obowiązek implementowania do krajowych porządków prawnych regulacji nadających odpowiednim organom uprawnienia do prowadzenia postępowania przymusowej restrukturyzacji poprzez zastosowanie instrumentów, takich jak przejęcie przedsiębiorstwa, instytucja pomostowa, wydzielenie aktywów, umorzenie lub konwersja długu, a także uprawnienia do dokonania umorzenia instrumentów kapitałowych w ramach postępowania restrukturyzacji lub na etapie poprzedzającym je oraz wprowadzała częściową harmonizację $\mathrm{w}$ kolejności zaspokajania roszczeń w postępowaniu upadłościowym poprzez nadanie uprzywilejowania wybranym kategoriom zobowiązań, w szczególności depozytom gwarantowanym.

Jak wskazano w uzasadnieniu projektu ustawy, efektem prac grupy roboczej powołanej przez Komitet Stabilności Finansowej było przygotowanie projektu ustawy, który został przekazany Komitetowi i skierowany przez Ministerstwo Finansów do dalszych prac w procesie legislacyjnym. W związku z koniecznością implementowania do krajowego porządku prawnego dyrektywy BRR projekt ustawy został odpowiednio do niej dostosowany. Zakres podmiotowy został rozszerzony w stosunku do pierwotnych założeń przedstawionych przez grupę roboczą Komitetu Stabilności Finansowej o firmy inwestycyjne, instytucje finansowe oraz spółki holdingowe będące podmiotami dominującymi wobec grup, w skład których wchodzi podmiot zagrożony niewypłacalnością. Dodatkowo projektodawca objął zakresem podmiotowym postępowania przymusowej re-

${ }^{6}$ M.in. w drodze Dyrektywy Parlamentu Europejskiego i Rady (UE) 2019/879 z dnia 20 maja 2019 r., zmieniającej dyrektywę 2014/59/UE w odniesieniu do zdolności do pokrycia strat i dokapitalizowania instytucji kredytowych i firm inwestycyjnych oraz dyrektywę 98/26/WE. 
strukturyzacji spółdzielcze kasy oszczędnościowo-kredytowe. Przyczynami takiego działania były złożona sytuacja w sektorze spółdzielczych kas oszczędnościowo-kredytowych, podobieństwo w zakresie świadczonych usług w stosunku do sektora bankowego oraz wzrost skali działalności kas?

Była to decyzja wykraczająca poza zakres transformacji Dyrektywy BRR, spod regulacji której wyłączone były i pozostają unie kredytowe, działające w poszczególnych państwach członkowskich (których desygnatem w Polsce są spółdzielcze kasy oszczędnościowo-kredytowe). Dyrektywa ta bowiem, w myśl jej art. 2 ust. 1 pkt 2, ma zastosowanie do instytucji kredytowych, zgodnie $z$ definicją zawartą w art. 4 ust. 1 pkt 1 rozporządzenia (UE) nr 575/2013, z wyjątkiem podmiotów, o których mowa w art. 2 ust. 5 dyrektywy 2013/36/UE. Te wyłączone podmioty to w Polsce spółdzielcze kasy oszczędnościowo-kredytowe i Bank Gospodarstwa Krajowego.

Ta decyzja legislacyjna była poprzedzona wprowadzeniem do Ustawy z dnia 5 listopada 2009 r. o spółdzielczych kasach oszczędnościowo-kredytowych, na mocy Ustawy z dnia 19 kwietnia 2013 r. o zmianie ustawy o spółdzielczych kasach oszczędnościowo-kredytowych oraz niektórych innych ustaw, która weszła w życie już w czerwcu 2013 r., a zatem na kilka lat wcześniej niż na Rzeczypospolitej Polskiej zaczął ciążyć obowiązek transformacji Dyrektywy BRR (gdy ta dyrektywa znajdowała się jeszcze na etapie projektowania), rozwiązań zbliżonych do wybranych instrumentów przymusowej restrukturyzacji. Obecnie funkcjonują one nadal, jako restrukturyzacja kas $\mathrm{w}$ rozumieniu ustawy o $\mathrm{BFG}^{8}$. Te rozwiązania to w szczególności przepisy art. 74c, dające Komisji Nadzoru Finan-

7 Uzasadnienie do projektu ustawy o Bankowym Funduszu Gwarancyjnym, systemie gwarantowania depozytów oraz przymusowej restrukturyzacji, druk sejmowy nr 215 Sejmu VIII kadencji.

${ }^{8}$ Szerzej na temat instytucji prawnej nadzoru nad kasami, sprawowanego przez Komisję Nadzoru Finansowego zob. P. Pelc, Nadzór Komisji Nadzoru Finansowego nad spółdzielczymi kasami oszczędnościowo-kredytowymi a nadzór nad otwartymi funduszami emerytalnymi, w: Prawo prywatne $w$ służbie społeczeństwu. Księga poświęcona pamięci Profesora Adama Jedlińskiego, red. P. Zakrzewski, D. Bierecki, Sopot 2019, s. 235-262. 
sowego możliwość wydania decyzji o przejęciu kasy, której wyrażony procentowo stosunek funduszy własnych do aktywów obniżył się poniżej 1\% (lub jej wybranych praw i zobowiązań), przez inną kasę lub przez bank. Decyzja taka może być zaskarżona do sądu administracyjnego $\mathrm{w}$ bardzo krótkim, siedmiodniowym terminie przez radę nadzorczą restrukturyzowanej kasy, jednakże wniesienie skargi nie wstrzymuje wykonania decyzji, a w przypadku uznania skargi za zasadną sąd orzeka jedynie o jej wydaniu $z$ naruszeniem prawa. Decyzja ma więc charakter nieodwracalny. Mocą nowelizacji z 19 kwietnia 2013 r. wprowadzono także szczególne zasady likwidacji kasy i instytucję zawieszenia jej działalności. Uprawnienia w zakresie tej pierwszej uregulowanej w polskim prawie restrukturyzacji, nawiązującej do regulacji Dyrektywy BRR, powierzono Komisji Nadzoru Finansowego ${ }^{9}$.

Rząd polski wystąpił do Komisji Europejskiej o wyrażenie zgody na wykorzystanie pomocy publicznej w ramach Programu kontrolowanej likwidacji (była to ówcześnie stosowana terminologia na określenie instytucji nazywanej obecnie przymusową restrukturyzacją) spółdzielczych kas oszczędnościowo-kredytowych ${ }^{10}$; w dniu 30 września 2013 r. zgoda taka została Polsce udzielona ${ }^{11}$. Decyzja ta jest konsekwentnie przedłużana ${ }^{12}$.

Regulacja art. 74c ustawy o SKOK (w 11 przypadkach, w tym 10 przejęć przez bank, jedno przejęcie przez inną kasę) oraz upadłość spółdzielczej kasy ogłoszona na wniosek Komisji Nadzoru Finan-

9 Regulacja ta wzbudziła bardzo poważne kontrowersje; została ona zaskarżona do Trybunału Konstytucyjnego wnioskiem Prezydenta RP, a także przez grupę posłów i senatorów. Trybunał Konstytucyjny jednakże w wyroku z dnia 31 lipca 2015 r., K 41/12 stwierdził, że jest ona zgodna z Konstytucją. Regulacja ta była także przedmiotem krytycznych głosów w literaturze prawniczej; zob. J. Skoczek, Kilka uwag o rzadowym projekcie ustawy o Bankowym Funduszu Gwarancyjnym, uporządkowanej likwidacji banków oraz zmianie niektórych innych ustaw z dnia 23 kwietnia 2013 roku, „Pieniądze i Więź” 2013, nr 2, s. 115.

${ }^{10}$ Credit Unions Orderly Liquidation Scheme.

11 Decyzja SA.37425 (2013/N) - Poland - Credit Unions Orderly Liquidation Scheme - Dz.U. C/210/2014.

12 Ostatnio do dnia 15 lipca 2021 r. decyzją o sygnaturze SA.56635. 
sowego (także w 11 przypadkach), a także dobrowolne połączenie kas na podstawie przepisów art. 96-102 ustawy Prawo spółdzielcze (w ośmiu przypadkach, kolejne postępowania w sprawie decyzji o zgodzie na połączenie są w toku) były wyłącznymi sposobami restrukturyzacji kas ${ }^{13}$. Nigdy nie zastosowano instytucji przymusowej restrukturyzacji kasy. W sytuacji zawieszenia działalności SKOK i złożenia wniosku o do sądu o ogłoszenie jej upadłości dochodziło do ziszczenia się warunku gwarancji depozytów i uruchomienia wypłaty przez BFG z tytułu gwarancji depozytów. W przypadku restrukturyzacji kas na podstawie przepisu art. 74c ustawy o SKOK dochodziło do uruchomienia pomocy publicznej w ramach Programu kontrolowanej likwidacji SKOK za zgodą Komisji Europejskiej poprzez udzielenie przez BFG dotacji na rzecz banku przejmującego i ewentualnie gwarancji na przejmowany przez niego portfel kredytowy (kasy restrukturyzowane wykorzystywały także pomoc stabilizacyjną, udzieloną ze środków funduszu stabilizacyjnego przez Kasę Krajową). Gdy dochodziło do połączeń dobrowolnych, wsparcia finansowego dla procesu restrukturyzacji udzielała wyłącznie Krajowa Spółdzielcza Kasa Oszczędnościowo-Kredytowa z funduszu stabilizacyjnego ${ }^{14}$.

Warto podkreślić, że zastosowanie instrumentów przymusowej restrukturyzacji jest możliwe wtedy i tylko wtedy, gdy jest ono konieczne $\mathrm{w}$ interesie publicznym (art. 101 ust. 7 pkt 3 ustawy o BFG). Przepis art. 101 ust. 10 tej ustawy definiuje działania podejmowane w interesie publicznym (nie definiuje tego, kiedy działania są konieczne w interesie publicznym, tylko kiedy są podejmowane $w$ interesie publicznym). Przepis ten stanowi, że dzia-

${ }^{13} \mathrm{Na}$ temat prawnej konstrukcji przejęcia kasy w drodze zastosowania instrumentu nadzorczego zob. P. Zakrzewski, w: A. Herbet, S. Pawłowski, P. Zakrzewski, Spółdzielcze kasy oszczędnościowo-kredytowe. Komentarz, Warszawa 2014, s. 452, 455 oraz D. Duda, Przejęcie spółdzielczej kasy oszczędnościowo-kredytowej na podstawie decyzji administracyjnej Komisji Nadzoru Finansowego, „Prawo i Więź” 2018, nr 23, s. 50-60.

14 Szerzej zob. J. Mędrzecka, Łączenie się spótdzielczych kas oszczędnościowo-kredytowych a restrukturyzacja i uporzadkowana restrukturyzacja kas, w: Prawo prywatne w służbie społeczeństwu, s. 187-201. 
łania są podejmowane w interesie publicznym, jeżeli są konieczne dla zapewnienia realizacji co najmniej jednego $z$ celów przymusowej restrukturyzacji określonych w art. 66, a osiągnięcie tych celów $\mathrm{w}$ takim samym stopniu nie jest możliwe $\mathrm{w}$ ramach sprawowanego nadzoru lub postępowania upadłościowego. $Z$ kolei art. 66 ustawy o BFG jako cele przymusowej restrukturyzacji wymienia:

- utrzymanie stabilności finansowej, w szczególności przez ochronę zaufania do sektora finansowego i zapewnienie dyscypliny rynkowej;

- ograniczenie zaangażowania funduszy publicznych lub prawdopodobieństwa ich zaangażowania wobec sektora finansowego lub jego poszczególnych podmiotów dla realizacji celów, o których mowa w pkt 1 oraz 3-5;

- zapewnienie kontynuacji realizowanych przez podmiot funkcji krytycznych;

- ochronę deponentów i inwestorów objętych systemem rekompensat;

- ochronę środków powierzonych podmiotowi przez jego klientów.

Wykładnia tego przepisu jest o tyle trudna, że ze zdania, iż działania są podejmowane $\mathrm{w}$ interesie publicznym tylko wtedy, gdy są konieczne dla zapewnienia jednego $z$ celów przymusowej restrukturyzacji, wynika, że zapewnienie takiego celu nie jest możliwe bez użycia instrumentu przymusowej restrukturyzacji. Jednakże przepis uzupełniono o zastrzeżenie, że osiągnięcie tych celów nie jest możliwe $\mathrm{w}$ ramach sprawowanego nadzoru lub postępowania upadłościowego. Wydaje się więc, że mamy tu do czynienia $z$ innym pojęciem konieczności niż to występujące w tradycyjnej konstrukcji warunku sine qua non. Chodzi tu raczej o taką przesłankę, że użycie instrumentu przymusowej restrukturyzacji ma przewagę nad zastosowaniem instrumentu nadzorczego lub nad postępowaniem upadłościowym $\mathrm{z}$ punktu widzenia realizacji celów określonych w art. 66 ustawy o $\mathrm{BFG}^{15}$.

${ }^{15}$ Warto podkreślić, że - mimo zastrzeżenia wskazującego literalnie na pierwszeństwo rozważenia możliwości osiągnięcia celów, o jakich mowa w art. 66 ust. 1 ustawy o BFG, przy użyciu instrumentu postępowania upadłościowego, 
Cel opisany w art. 66 pkt 1 ustawy o BFG należy rozumieć jako utrzymanie stabilności finansowej całego rynku, w szczególności przez ochronę zaufania, stąd też niewielki udział kas w rynku usług finansowych wydaje się przeczyć możliwości zaistnienia konieczności zastosowania instrumentu przymusowej restrukturyzacji (versus instrumenty nadzorcze) w stosunku do którejkolwiek $\mathrm{z}$ kas. Trudno jest bowiem wyobrazić sobie sytuację, w której prawidłowo używane instrumenty nadzorcze nie pozwoliłyby uniknąć zagrożenia dla utrzymania stabilności finansowej całego rynku finansowego, które mogłoby wynikać $z$ problemów finansowych którejkolwiek z kas. Ze względu na nieznaczny udział całego sektora SKOK, w porównaniu $z$ sektorem bankowym, w całym rynku (wynoszący 0,6\% jako porównanie aktywów całego sektora SKOK do sumy aktywów 10 największych banków) zawsze jest możliwe zabsorbowanie praw i zobowiązań kasy, której działalność zakończyłaby się niepowodzeniem, jeśli nie w ramach sektora SKOK, to w ramach sektora bankowego. Ta okoliczność powoduje, że w przypadku nawet naj-

wskazuje się w literaturze, iż ,podmiot, który w rozumieniu u.b.f.g. [ustawy z 2016 r. o Bankowym Funduszu Gwarancyjnym, systemie gwarantowania depozytów oraz przymusowej restrukturyzacji - J.M. M.] jest "zagrożony upadłością", nie może zostać zakwalifikowany do ogłoszenia upadłości w rozumieniu przepisów prawa upadłościowego lub bankowego. W pierwszej kolejności powinny zostać zastosowane instrumenty przymusowej restrukturyzacji uregulowane w u.b.f.g. Upadłość uregulowana w przepisach prawa upadłościowego lub bankowego znajdzie zastosowanie w przypadku, gdy zawiodą lub niemożliwe do zastosowania będą instrumenty przymusowej restrukturyzacji zawarte w u.b.f.g.". Tak M. Medyński i P. Zimmermann, Ustawa o Bankowym Funduszu Gwarancyjnym, systemie gwarantowania depozytów oraz przymusowej restrukturyzacji - wielkie zmiany $i$ ich przyczyny, "Monitor Prawa Bankowego” 2017, nr 2, s. 96-108. Wynika to stąd, że w istocie trudno jest wyobrazić sobie, aby przy zastosowaniu instrumentu w postaci postępowania upadłościowego w ogóle dało się osiągnąć taki cel jak ochrona zaufania do rynku finansowego, ograniczenie zaangażowania środków publicznych (biorąc pod uwagę, że w razie wystąpienia $z$ wnioskiem o ogłoszenie upadłości banku lub kasy dochodzi do ziszczenia się warunku gwarancji zgromadzonych w banku lub kasie depozytów i wypłaty z tego tytułu na rzecz deponentów), a osiągnięcie celu w postaci kontynuowania funkcji krytycznych w przypadku upadłości banku lub kasy jest w ogóle niemożliwe. 
większej z kas rozważanym przez Bankowy Fundusz Gwarancyjny w streszczeniu planu przymusowej restrukturyzacji instrumentem takiej przymusowej restrukturyzacji jest jedynie przejęcie jej przedsiębiorstwa przez bank, a zatem narzędzie, którego cele zawsze $\mathrm{z}$ istoty rzeczy da się zrealizować przy użyciu środka nadzoru ${ }^{16}$. Pamiętajmy, że w stosunku do kas instytucja przejęcia kasy lub jej wybranych praw i obowiązków została wprowadzona do ustawy o SKOK właśnie jako zapowiedź rodzącej się idei przymusowej restrukturyzacji, z założeniem, że przejęcie następuje w drodze decyzji natychmiast wymaganej i nieodwracalnej (która nie może być przez sąd uchylona, o bardzo ograniczonej możliwości zaskarżenia, węższej nawet niż możliwość zaskarżenia decyzji BFG podejmowanych $\mathrm{w}$ ramach przymusowej restrukturyzacji ${ }^{17}, \mathrm{z}$ założeniem przezna-

16 Jak wskazują M. Medyński i P. Zimmerman, Ustawa o Bankowym Funduszu Gwarancyjnym, s. 96-108: „Zasadniczym instrumentem przymusowej restrukturyzacji jest przejęcie przedsiębiorstwa. Przepisy dotyczące tej regulacji są zawarte w rozdziale 13 u.b.f.g. [...] Celem tego uregulowania jest możliwość sprzedaży części lub całości praw i majątkowych lub zobowiązań podmiotu w restrukturyzacji nabywcy lub też nabywcom $z$ sektora prywatnego, co pozwoli na kontynuację działalności podmiotu przejmowanego. Dzięki temu unika się negatywnych skutków, które byłyby nie do uniknięcia przez klientów podmiotu w restrukturyzacji w przypadku zaprzestania świadczenia usług na ich rzecz".

$17 \mathrm{~W}$ przypadku przejęcia nadzorczego uprawnienie do zaskarżenia decyzji o przejęciu kasy przysługuje tylko jej radzie nadzorczej i uczestnikom postępowania na prawach strony (w praktyce była nim Kasa Krajowa), w przypadku przejęcia stosowanego jako instrument przymusowej restrukturyzacji prawo zaskarżenia decyzji przysługuje także każdemu, kogo interes prawny został naruszony decyzją (art. 103 ust. 5 ustawy o BFG). Na tle spraw dotyczących przejęcia kas zdarzały się także orzeczenia odmawiające Kasie Krajowej, jako podmiotowi uczestniczącemu w postępowaniu administracyjnym na prawach strony na podstawie przepisu art. 31 Kodeksu postępowania administracyjnego prawa do zaskarżenia decyzji, jednak orzeczenie to miało charakter odosobniony (wyrok Naczelnego Sądu Administracyjnego z dnia 7 listopada 2019 r., II GSK 3182/17, Lex nr 2755204; postanowienie WSA w Warszawie $z$ dnia 3 marca 2015 r., VI SA/Wa 3203/14, Lex nr 1962228). Natomiast obecnie jesteśmy świadkami kształtowania się linii orzeczniczej określającej, jakim podmiotom i w jakich sytuacjach przysługuje interes prawny w zakresie zaskarżania decyzji Bankowego Funduszu Gwarancyjnego w przedmiocie zastosowania instrumentu przymusowej restrukturyzacji (postanowienia Wojewódzkiego Sądu Administracyjnego w Warszawie z dnia 30 czerwca 2020 r., VI SA/Wa 
czenia całości funduszy własnych restrukturyzowanej kasy na pokrycie jej strat). Wprowadzone rozwiązanie stanowi najdalej idącą realizację założeń przymusowej restrukturyzacji, opisanych później w BRRD. Jeśli więc do zrealizowania celu w postaci utrzymania stabilności finansowej rynku, w szczególności przez ochronę zaufania do sektora finansowego, służyć mógłby instrument przymusowej restrukturyzacji w postaci przejęcia przedsiębiorstwa kasy, to nie zaistnieje sytuacja, w której celu tego nie dałoby się zrealizować przy użyciu instrumentu nadzorczego w postaci przejęcia kasy przez inną kasę lub bank na mocy przepisu art. 74c ustawy o skok.

Nie bez znaczenia jest też, podkreślona w przepisie art. 66 ust. 1 ustawy o BFG, rola ochrony zaufania do rynku finansowego, a więc kwestia wizerunkowa, w ramach dążenia do utrzymania stabilności finansowej rynku. W przypadku stosowania przejęcia jako instrumentu nadzorczego $z$ art. 74c ustawy o SKOK ${ }^{18}$ w zasadzie nie odnotowano zaniepokojenia rynku; zupełnie inaczej stało się w przypadku użycia po raz pierwszy instrumentu przymusowej restrukturyzacji wobec Banku Spółdzielczego w Sanoku, co odbiło się szerokim echem w środkach masowego przekazu ${ }^{19}$.

1190/20, Lex nr 3040584; z dnia 15 czerwca 2020 r., VI SA/Wa 680/20, Lex nr 3035690; z dnia 15 czerwca 2020 r., VI SA/Wa 681/20, Lex nr 3035734; z dnia 14 maja 2020 r., VI SA/Wa 790/20, Lex nr 3018089), która wydaje się zmierzać do wypracowania bardzo restrykcyjnego ujęcia interesu prawnego jako przesłanki skutecznego wniesienia skargi od takiej decyzji.

18 Takiego zaniepokojenia nie odnotowano także w związku wydaną w dniu 21 stycznia 2020 r. decyzją Komisji Nadzoru Finansowego (KNF), która działając na podstawie art. 146b ust. 1 ustawy Prawo bankowe, jednogłośnie zdecydowała o przejęciu Banku Spółdzielczego w Dołhobyczowie (bank przejmowany) przez Powiatowy Bank Spółdzielczy w Zamościu (bank przejmujący) za zgodą banku przejmującego.

${ }^{19}$ Można tu wskazać takie tytuły materiałów prasowych, jak: Kłopoty PBS Banku. Podkarpacie przeciera oczy ze zdumienia, klienci licza utracone miliony, https://spidersweb.pl/bizblog/pbs-sanok-bfg-restrukturyzacja/ czy też Obligacje ryzykowne jak akcje. Po PBS $w$ Sanoku kolejne resolution jest tylko kwestia czasu, https://www.stockwatch.pl/wiadomosci/obligacje-ryzykowne-jak-akcjepo-pbs-w-sanoku-kolejne-resolution-jest-tylko-kwestia-czasu,obligacje, 254646 (dostęp: 03.03.2021 r.), w którym napisano: „W styczniu o Podkarpackim Banku Spółdzielczym w Sanoku usłyszała cała Polska. Zarząd banku z dnia na dzień 
Kolejnym celem przymusowej restrukturyzacji wskazanym w art. 66 ust. 1 ustawy o BFG jest ograniczenie zaangażowania funduszy publicznych lub prawdopodobieństwa ich zaangażowania wobec sektora finansowego lub jego poszczególnych podmiotów dla realizacji celów, o których mowa w pkt 1 oraz 3-5. Również w tym aspekcie nie sposób wykazać wyższości przejęcia przedsiębiorstwa kasy w ramach procedury przymusowej restrukturyzacji nad przejęciem w procedurze nadzorczej. Rozmiar wsparcia publicznego będzie w obu przypadkach wyznaczony w taki sam sposób, w odniesieniu do różnicy między wartością przejmowanego czynnego majątku a wartością przejmowanych zobowiązań (która wyznacza rozmiar udzielanej dotacji), $z$ jednoczesnym udzieleniem gwarancji $w$ relacji do wartości przejmowanego portfela kredytowego.

Zgodnie $z$ treścią przepisu art. 112 ust. 3 ustawy o BFG, Fundusz może udzielić wsparcia $z$ funduszy przymusowej restrukturyzacji $\mathrm{w}$ celu zastosowania instrumentu przejęcia przedsiębiorstwa lub przeniesienia, o którym mowa w art. 188 ust. 1, polegającego na: 1) udzieleniu gwarancji całkowitego lub częściowego pokrycia strat wynikających $z$ ryzyka związanego ze wszystkimi lub wybranymi prawami majątkowymi lub zobowiązaniami podmiotu w restrukturyzacji; 2) udzieleniu dotacji w celu pokrycia różnicy między wartością zobowiązań i wartością praw majątkowych podmiotu w restrukturyzacji, określonych na podstawie oszacowania, o którym mowa w art. 137 ust. 2 i 3, w części niepokrytej środkami, o których mowa w art. 179 lub art. 188 ust. 5.

Z kolei przepis art. 264 ustawy o BFG określa zasady udzielania wsparcia dla procesu przejęcia nadzorczego. Zgodnie $z$ tym przepisem, Fundusz może udzielać wsparcia finansowego na rzecz działalności kasy w przypadku jej przejęcia, przejęcia jej wybranych praw majątkowych lub wybranych zobowiązań lub w razie nabycia

uległ rozwiązaniu po tym, jak Bankowy Fundusz Gwarancyjny ogłosił wobec niego przymusową restrukturyzację i przeniósł obsługę jego klientów do specjalnie w tym celu utworzonego banku pomostowego. Ogólnopolskie telewizje pokazywały kolejki klientów czekających na wypłatę depozytów, a media branżowe odmieniały przez wszystkie przypadki słowo "resolution" i rozpisywały się na temat strat inwestorów". 
przedsiębiorstwa tej kasy w likwidacji, jego zorganizowanej części lub wybranych praw majątkowych podmiotowi przejmującemu lub nabywcy. Wsparcie może zostać również udzielone w sytuacji objęcia przez Fundusz akcji banku przejmującego. Może ono nastąpić poprzez: 1) objęcie akcji banku przejmującego; 2) udzielenie pożyczki lub gwarancji; 3) udzielenie gwarancji całkowitego lub częściowego pokrycia strat wynikających $z$ ryzyka związanego $z$ przejmowanymi lub nabywanymi prawami majątkowymi lub przejmowanymi zobowiązaniami; 4) udzielenie dotacji na pokrycie różnicy między wartością przejmowanych lub nabywanych praw majątkowych i przejmowanych zobowiązań z tytułu środków gwarantowanych na rachunkach deponentów kasy do wysokości łącznej maksymalnej kwoty z tytułu gwarancji w kasie liczonej jako suma środków gwarantowanych na rachunkach deponentów kasy, w której stwierdzono niebezpieczeństwo niewypłacalności. W obu więc przypadkach kwotę wsparcia publicznego określa się jako kwotę, która podmiotowi przejmującemu skompensuje ciężar przejmowanego przedsiębiorstwa kasy, w tym ryzyko związane $z$ przejmowanym portfelem kredytowym.

Zachowanie realizowanych przez podmiot funkcji krytycznych (w znaczeniu funkcji określonych jako krytyczne przez samą jednostkę) wydaje się zapewnione w każdym przypadku przejęcia kasy lub jej przedsiębiorstwa przez inną kasę lub bank. $Z$ uwagi bowiem na wąski, ustawowo wyznaczony zakres działalności kas trudno sobie wyobrazić kasę przejmującą lub bank przejmujący, które nie wykonywałby usług finansowych, należących do tego zakresu. Przede wszystkim jednak, zgodnie $z$ przepisem art. 2 pkt 17 ustawy o BFG, funkcje krytyczne to usługi, operacje lub inna działalność podmiotu lub grupy, których zaprzestanie mogłoby prowadzić, w jednym lub kilku państwach będących członkami Unii Europejskiej, do zakłóceń w funkcjonowaniu gospodarki lub zagrozić stabilności finansowej ze względu na wielkość podmiotu lub grupy, ich udział w rynku, złożoność, działalność transgraniczną, powiązania gospodarcze lub finansowe, za szczególnym uwzględnieniem możliwości wykonywania tych usług, operacji lub innej działalności przez inne podmioty. Ze względu na wskazany wyżej nieznaczny udział kas w rynku finansowym wydaje się niemożliwe, 
aby w ogóle można było mówić o pełnieniu przez którąkolwiek $z$ kas funkcji krytycznych w rozumieniu przywołanego przepisu. Dodatkowo warto podkreślić, że kasy - oprócz świadczenia usług na rzecz osób fizycznych, mogą świadczyć usługi na rzecz jednostek organizacyjnych, wskazanych w art. 10 ust. 2 ustawy o SKOK. Są to podmioty tzw. trzeciego sektora i ich udział w gospodarce jest co do zasady nieznaczny, najistotniejsze jest jednak to, że środki finansowe gromadzone w kasie przez podmiot należący do którejkolwiek $z$ kategorii członków niebędących osobami fizycznymi są objęte gwarancjami BFG na równi $z$ depozytami osób fizycznych (art. 21 ustawy o BFG, a wyłączenia $z$ objęcia gwarancjami, opisane w art. 22 tej ustawy, nie dotyczą, poza innymi kasami i Kasą Krajową, podmiotów mogących być członkami SKOK). Warto zaznaczyć, że nieznaczny jest nie tylko udział kas w rynku finansowym, ale także udział przedsiębiorców oraz podmiotów trzeciego sektora w korzystaniu z usług finansowych SKOK. Udział kredytów konsumpcyjnych w portfelu kas przewyższa 97\%, a ich udział w obecnie realizowanych akacjach kredytowych - nawet 99\%.

Kolejnymi celami przymusowej restrukturyzacji, opisanymi w art. 66 ust. 1 ustawy o BFG, są ochrona deponentów i inwestorów objętych systemem rekompensat oraz ochrona środków powierzonych podmiotowi przez jego klientów. Ochrona deponentów i inwestorów objętych systemem rekompensat $\mathrm{z}$ istoty rzeczy nie może mieć zastosowania do kas, chodzi tu bowiem o system rekompensat, o jakim mowa w art. 133 ust. 1 Ustawy $z$ dnia 29 lipca 2005 r. o obrocie instrumentami finansowymi, i dotyczy on domów maklerskich i ich klientów ${ }^{20}$. Ochrona środków powierzonych podmiotowi przez jego klientów w przypadku kasy w razie wykorzystania instrumentu nadzorczego $\mathrm{w}$ postaci jej przejęcia, zawsze jest zapewniona,

${ }^{20}$ Tekst jednolity: Dz.U. z 2020 r. poz. 89. W myśl przepisu art. 133 ust. 1 ustawy o obrocie instrumentami finansowymi Krajowy Depozyt tworzy i prowadzi obowiązkowy system rekompensat w celu gromadzenia środków na ich wypłaty inwestorom. Zgodnie zaś z przepisem art. 132 ust. 1 pkt 21 tej ustawy za inwestora uważa się osobę fizyczną, osobę prawną albo jednostkę organizacyjną nieposiadającą osobowości prawnej, na rzecz której dom maklerski świadczy jedną z usług. 
członkowie kasy stają się bowiem klientami banku i kontynuują nabyte $\mathrm{w}$ kasie prawa podmiotowe, wynikające $\mathrm{z}$ zawartych umów rachunku bankowego.

Obecnie także w ustawie Prawo bankowe (w art. 146b) znajduje się regulacja dotycząca przejęcia banku w trybie nadzorczym (na podstawie decyzji Komisji Nadzoru Finansowego), wprowadzona do tej ustawy na mocy Ustawy z dnia 9 listopada 2018 r. o zmianie niektórych ustaw w związku ze wzmocnieniem nadzoru nad rynkiem finansowym oraz ochroną inwestorów na tym rynku. Zgodnie z tym przepisem przejęcie jest możliwe, jeśli fundusze własne banku spadną poniżej poziomu określonego w przepisie art. 128 ust. 1 ustawy Prawo bankowe. W art. 146f ustawy Prawo bankowe uregulowano kwestie wypłaty na rzecz akcjonariuszy banku przejętego lub wypowiedzenia członkostwa członkom przejętego banku spółdzielczego i rozliczenia $z$ tymi byłymi członkami oraz odszkodowania za szkodę powstałą na skutek przejęcia banku. Dla zaskarżenia decyzji wprowadzono krótki termin i ograniczony zakres podmiotów do tego uprawnionych, jednakże nie ustanowiono regulacji, zgodnie $z$ którą decyzja o przejęciu banku na podstawie przepisu art. 146b ustawy Prawo bankowe, w razie jej zaskarżenia do sądu, nie mogłaby być uchylona. Przede wszystkim jednak przejęcie banku, o jakim mowa w art. 146b ustawy Prawo bankowe, może być stosowane szerzej niż tylko w przypadku zagrożenia jego niewypłacalnością w zasadzie w razie każdego spadku funduszy własnych poniżej wymaganego poziomu, a w przypadku banku spółdzielczego także wtedy, gdy nie wykonuje on obowiązku zrzeszeniowego. Regulacja przejęcia banku w trybie nadzorczym $\mathrm{z}$ art. 146b i następnych ustawy Prawo bankowe nie jest więc $\mathrm{w}$ pełni odpowiednikiem regulacji przejęcia kasy w trybie art. 74c i następnych ustawy o SKOK; ta ostatnia w znacznie większym stopniu, tj. w całości, spełnia wymagania stawiane instrumentom przymusowej restrukturyzacji. Przede wszystkim jednak wprowadzenie w Prawie bankowym regulacji dotyczącej przejęcia banku jako instrumentu nadzorczego nastąpiło w sytuacji, w której - z uwagi na ogromne zróżnicowanie banków pod względem rozmiaru działalności - nie jest wykluczone użycie wobec niektórych banków instrumentu przymusowej restrukturyzacji w postaci innej niż przejęcie przedsiębiorstwa, czyli w postaci instytucji pomostowej. 
Zgodnie $z$ przepisem art. 110 ust. 1 ustawy o BFG instrumentami przymusowej restrukturyzacji są: przejęcie przedsiębiorstwa, instytucja pomostowa, umorzenie lub konwersja zobowiązań, wydzielenie praw majątkowych, przy czym ten ostatni instrument może być zastosowany tylko łącznie $z$ innym instrumentem przymusowej restrukturyzacji (art. 110 ust. 2 tej ustawy). Zgodnie $z$ przepisem art. 110 ust. 6 ustawy o BFG Fundusz dokonuje umorzenia lub konwersji instrumentów kapitałowych przed lub równocześnie $z$ użyciem instrumentów przymusowej restrukturyzacji, jeżeli w wyniku zastosowania tych instrumentów wierzyciele ponieśliby straty lub ich zobowiązania podlegałyby konwersji. Tak naprawdę również umorzenie lub konwersja instrumentów kapitałowych występuje więc w połączeniu $z$ innym instrumentem przymusowej restrukturyzacji i ma charakter uboczny w stosunku do jednego $z$ dwóch głównych instrumentów, jakimi są przejęcie przedsiębiorstwa podmiotu restrukturyzowanego i instytucja pomostowa. Oprócz umorzenia lub konwersji, ujętego jako instrument przymusowej restrukturyzacji, w ustawie o BFG uregulowano także umorzenie lub konwersję instrumentów kapitałowych bez wydawania decyzji o wszczęciu przymusowej restrukturyzacji ${ }^{21}$. W istocie zatem do tego, aby dla

${ }^{21}$ Jak wskazują M. Medyński, P. Zimmerman, Ustawa o Bankowym Funduszu Gwarancyjnym, s. 262-264: „Pierwszy przypadek uregulowany jest w art. 70 ust. 1 pkt 2 u.b.f.g., zgodnie $z$ którym do umorzenia lub konwersji instrumentów kapitałowych może dojść w ramach przymusowej restrukturyzacji, łącznie $z$ jednym lub kilkoma pozostałymi instrumentami restrukturyzacji, np. utworzeniem instytucji pomostowej. W drugim przypadku do umorzenia lub konwersji instrumentów kapitałowych może dojść bez wydania decyzji BFG o wszczęciu postępowania przymusowej restrukturyzacji, jednak tylko w ściśle określonych sytuacjach, tj. gdy podmiot jest zagrożony upadłością, a działania te są niezbędne w interesie publicznym (art. 70 ust. 2 u.b.f.g.)" Szerzej M. Medyński, w: Ustawa o bankowym Funduszu Gwarancyjnym, systemie gwarantowania depozytów oraz przymusowej restrukturyzacji. Komentarz, red. P. Zawadzka, P. Zimmerman, R. Sura, Warszawa 2017, s. 181-183. Dziś w kasach nie ma żadnych instrumentów kapitałowych, innych niż te wchodzące w skład funduszy własnych (są to udziały w spółdzielczych kasach oszczędnościowo-kredytowych oraz zobowiązania podporządkowane, udzielone kasom w ramach funkcji stabilizacyjnej przez Kasę Krajową, zaliczone do funduszy własnych kas na mocy decyzji Komisji Nadzoru Finansowego), będące środ- 
osiągnięcia wobec kasy celów przymusowej restrukturyzacji, o jakich mowa w art. 66 ust. 1 ustawy o BFG, konieczne było zastosowanie instrumentu przymusowej restrukturyzacji, musiałaby zachodzić sytuacja, w której nie byłoby wystarczające skorzystanie $z$ instrumentu przejęcia jej przedsiębiorstwa lub przejęcia jej przedsiębiorstwa w połączeniu $z$ wydzieleniem praw majątkowych czy też umorzeniem lub konwersją instrumentów kapitałowych. Warto bowiem ponownie podkreślić, że ustawa o SKOK w art. 74c reguluje nie tylko przejęcie kasy w całości, ale także przejęcie jej wybranych praw i zobowiązań, zatem również wydzielenie praw majątkowych znajduje w przypadku kas swój odpowiednik w instrumencie nadzorczym, a przejęcie w trybie nadzorczym zawsze, w myśl przepisu art. 74i ust. 6 ustawy o SKOK, zawsze wiąże się z przeznaczeniem funduszy własnych w pierwszej kolejności na pokrycie strat przejmowanej kasy ${ }^{22}$. Musiałaby zatem zachodzić sytuacja, w której koniecznym instrumentem przymusowej restrukturyzacji byłaby instytucja pomostowa, a skorzystanie $z$ takiego narzędzia wydaje się uzasadnione tylko i wyłącznie w przypadkach, w których znaczny jest zarówno rozmiar działalności podmiotu w restrukturyzacji, jak i stopień skomplikowania tej działalności, uzasadniający wniesienie części majątku podmiotu w restrukturyzacji do instytucji pomostowej w celu utrzymania w ten sposób jego funkcji krytycznych ${ }^{23}$.

kami pomocowymi, choć niepublicznymi i wniesione przez instytucję będącą elementem sieci bezpieczeństwa w celu ustabilizowania sytuacji finansowej kasy. Pozostałe zobowiązania kas wobec wierzycieli to ich zobowiązania wobec deponentów, objęte gwarancjami Bankowego Funduszu Gwarancyjnego (z wyjątkiem pojedynczych depozytów przewyższających kwoty gwarantowane lub depozytów kadry zarządzającej, wyłączonych od objęcia gwarancjami), zatem zobowiązania, które nie mogą podlegać umorzeniu lub konwersji. Trudno więc wyobrazić sobie sytuację, w której celowe byłoby, de lege lata, zastosowanie wobec kasy instrumentu umorzenia lub konwersji zobowiązań.

22 Ten instrument nadzorczy nie był nigdy dotąd stosowany w praktyce.

${ }^{23}$ Zgodnie $\mathrm{z}$ przepisem art. 2 ust. 1 pkt 26 ustawy o BFG instytucja pomostowa to podmiot, którego jedynym akcjonariuszem lub podmiotem dominującym jest Fundusz, utworzony w celu przeniesienia na ten podmiot praw udziałowych podmiotu w restrukturyzacji, jego przedsiębiorstwa albo praw majątkowych lub zobowiązań podmiotu w restrukturyzacji w celu kontynuowania 
Przy ocenie teoretycznej możliwości ziszczenia się wobec którejkolwiek z kas przesłanki konieczności podjęcia działań z zakresu przymusowej restrukturyzacji w interesie publicznym istotne znaczenie ma treść Komunikatu bankowego, czyli Komunikatu Komisji Europejskiej $^{24} \mathrm{w}$ sprawie stosowania od dnia 1 sierpnia 2013 r. reguł pomocy państwa w odniesieniu do środków wsparcia na rzecz banków w kontekście kryzysu finansowego, 2013/C 216/01. W pkt 86 rozdziału 6.4 wskazuje się, że kwota równowartości 3 mld euro, czyli aktualnie ok. 13,2 mld zł, jest minimalną kwotą wyznaczającą istotność pomocy z punktu widzenia wspólnego rynku. Aktywa 10 największych banków w Polsce na koniec I kwartału 2020 r. wynosiły ok 1459 mld zł, podczas gdy aktywa wszystkich kas łącznie 9322692680 zł, w tym aktywa Kasy Stefczyka 6806397320 zł, czyli odpowiednio 0,6\% i 0,4\% aktywów 10 największych banków). Warto zwrócić uwagę także na niewielkie rozmiary większości kas (tylko trzy z nich posiadają więcej niż 200 mln aktywów, niemal połowa kas nie przekracza $50 \mathrm{mln}$ aktywów) oraz na niewielki stopień skomplikowania działalności kas (jest ona ograniczona do najprostszych usług finansowych, takich jak przyjmowanie lokat, udzielanie kredytów i pożyczek oraz świadczenie usług płatniczych, a inwestycje kas w praktyce ograniczone są do lokat w Kasie Krajowej, lokat w bankach i obligacji skarbowych). Powyższe okoliczności decydują o tym, że prawdopodobieństwo ziszczenia się w stosunku do którejkolwiek z kas przesłanki uruchomienia jednego spośród instrumentów przymusowej restrukturyzacji, czyli przesłanki interesu publicznego uzasadniającego konieczność zastosowania takiego instrumentu (art. 101 ust. 7 pkt 3 ustawy o BFG), jest znikome,

w całości lub części działalności prowadzonej przez podmiot w restrukturyzacji. Jak wskazuje P. Zimmerman, w: M. Medyński, P. Zimmerman, Ustawa o bankowym Funduszu gwarancyjnym, s. 264-265, ostatecznym celem instytucji pomostowej jest takie uporządkowanie spraw podmiotu w restrukturyzacji, aby wykorzystać je w sposób maksymalnie efektywny ekonomicznie.

${ }^{24}$ Komisja Europejska, Komunikat Komisji w sprawie stosowania od dnia 1 sierpnia 2013 r. reguł pomocy państwa w odniesieniu do środków wsparcia na rzecz banków w kontekście kryzysu finansowego („komunikat bankowy”), Dz.Urz.UE. C. z 2013 r. Nr 216, s. 1. 
a może nawet $z$ istoty rzeczy niemożliwe. Aktywa całego sektora SKOK nie mają równowartości 3 mld euro, a aktywa największej z kas, czyli SKOK im. Franciszka Stefczyka, osiągają jedynie około połowy tej kwoty.

Jak wskazuje Bankowy Fundusz Gwarancyjny w pytaniach i odpowiedziach dotyczących przymusowej restrukturyzacji: „Ostatni kryzys finansowy pokazał, że państwa członkowskie Unii nie miały odpowiednich instrumentów do likwidacji dużych instytucji finansowych zagrożonych bankructwem, które ze względu na swoją złą sytuację nie były w stanie samodzielnie kontynuować działalności. Jednocześnie występowało ryzyko systemowe. Istniały obawy, że niekontrolowane bankructwo instytucji "zbyt dużych, żeby upaść», spowoduje zagrożenie dla klientów i całej gospodarki. Nie mając odpowiednich instrumentów do dyspozycji, państwa członkowskie ratowały zagrożone podmioty ze swoich budżetów. Komisja Europejska uznała, że podatnicy nie powinni ponosić kosztów ratowania instytucji „zbyt dużych, żeby upaść”. Podjęto decyzję, że odpowiedzialność powinna spadać przede wszystkim na właścicieli i w dalszej kolejności na wierzycieli zagrożonych instytucji” ${ }^{25}$. Stanowisko to potwierdza, że przymusowa restrukturyzacja jest instytucją przeznaczoną dla podmiotów zbyt dużych, by dotychczasowe instrumenty, czyli instrumenty nadzorcze i upadłościowe, były wobec nich wystarczające. Rozbudowanie instrumentów nadzorczych wobec kas o rozwiązania wprowadzone w ustawie $z$ dnia 19 kwietnia 2013 r., w szczególności dodanie w art. 74c ustawy o SKOK instrumentu przejęcia kasy lub jej wybranych praw i zobowiązań przez inną kasę lub bank, powoduje, że na gruncie obowiązującego systemu prawnego logicznie wykluczone jest zaistnienie sytuacji, w której możliwe byłoby zastosowanie wobec którejkolwiek z kas instytucji prawnej przymusowej restrukturyzacji. Wykluczone jest bowiem zaistnienie sytuacji, w której nie byłoby możliwe osiągnięcie, mogących znaleźć odniesienie do kas, celów przymusowej restrukturyzacji opisanych w art. 66 ust. 1 ustawy o BFG za pomocą instrumentu nadzorczego przejęcia, o jakim mowa w art. 74c ustawy o SKOK.

${ }^{25}$ https://www.bfg.pl/przymusowa-restrukturyzacja/przymusowa-restrukturyzacja-w-pytaniach-i-odpowiedziach/ (dostęp: 03.03.2021 r.) 


\section{STRESZCZENIE}

Kilka uwag co do zasadności utrzymywania

w polskim systemie prawnym instytucji

przymusowej restrukturyzacji spółdzielczych kas

oszczędnościowo-kredytowych

Przedmiotem artykułu są rozważania nad wzajemną relacją instytucji prawnej restrukturyzacji spółdzielczych kas oszczędnościowo-kredytowych, uregulowanej przede wszystkim w przepisach Ustawy z dnia 5 listopada 2009 r. o spółdzielczych kasach oszczędnościowo-kredytowych (ustawa o SKOK), która obejmuje kompetencje nadzorcze Komisji Nadzoru Finansowego oraz instytucji prawnej przymusowej restrukturyzacji kas, uregulowanej w przepisach Ustawy z dnia 10 czerwca 2016 r. o Bankowym Funduszu Gwarancyjnym (ustawa o BFG). Wprowadzona w 2013 r. do ustawy o SKOK konstrukcja prawna przejęcia kasy lub jej wybranych praw i zobowiązań przez inną kasę lub przez bank na mocy decyzji Komisji Nadzoru Finansowego, stanowiąca główny element instytucji prawnej restrukturyzacji kas, miała swoje źródło w projektowanych na szczeblu europejskim przepisach dotyczących przymusowej restrukturyzacji (zwanej też uporządkowaną likwidacją), w 2016 r. wprowadzonych do polskiego porządku prawnego ustawą o BFG. Dokonując tej transformacji, polski ustawodawca zdecydował o objęciu zakresem przymusowej restrukturyzacji także kasy, choć są one wyłączone spod inkorporowanej Dyrektywy ustanawiającej ramy na potrzeby prowadzenia działań naprawczych oraz restrukturyzacji w odniesieniu do instytucji kredytowych i firm inwestycyjnych. Analiza porównywanych regulacji prawnych prowadzi do wniosku, że przyznanie przez ustawodawcę Komisji Nadzoru Finansowego kompetencji do wydawania decyzji o przejęciu kasy lub jej wybranych praw i zobowiązań przez inną kasę lub bank, (przy jednoczesnym zapewnieniu m.in. niewzruszalności tej decyzji, szczególnego, bardzo ograniczającego prawa skarżących, trybu jej zaskarżenia, skutków majątkowych decyzji w postaci przeznaczenia funduszy własnych przejmowanego podmiotu na pokrycie strat, czyli znamion charakterystycznych dla decyzji podejmowanych w ramach procesu uporządkowanej restrukturyzacji), powoduje, że zawsze możliwe jest - w odniesieniu do kas - osiągnięcie celów uporządkowanej restrukturyzacji poprzez zastosowanie tego właśnie instrumentu nadzorczego. Ustawa o BFG stanowi zaś, że instrumenty przymusowej restrukturyzacji mogą być zastosowane wtedy i tylko wtedy, gdy takiego celu nie można osiągnąć za pomocą środków nadzorczych. Taka sytuacja 
powoduje podanie w wątpliwość, już w ujęciu teoretycznym, możliwości użycia wobec kas instrumentów przymusowej restrukturyzacji. Wątpliwość ta jeszcze pogłębia się w świetle doświadczeń praktycznych, które potwierdzają przekazywanie przez BFG środków na wsparcie restrukturyzacji kas już od 2014 r., w ramach rządowego programu uporządkowanej likwidacji kas, zaakceptowanego kolejnymi decyzjami Komisji Europejskiej, właśnie w przypadkach wydania przez KNF decyzji o przejęciu kasy przez bank na podstawie przepisu art. 74c ustawy o SKOK.

Słowa kluczowe: spółdzielcza kasa oszczędnościowo-kredytowa; bank; przymusowa restrukturyzacja; przejęcie; nadzór; Bankowy Fundusz Gwarancyjny

\section{SUMMARY}

\section{A few remarks on the expediency of maintaining the institution of resolution of cooperative savings and credit unions in the Polish legal system}

The paper reflects on mutual relationship between the restructuring of Polish cooperative savings and credit unions (the "credit unions" or SKOK, as the Polish abbreviation of the entities reads) regulated primarily by the Act of 5 November, 2009 on Cooperative Savings and Credit Unions (the "Credit Union Act"), which sets out the supervisory powers of the Polish Financial Supervision Authority in that respect, and the legal institution of credit union resolution, as governed by the Act of 10 June, 2016 on the Bank Guarantee Fund (the "BGF Act"), with the powers of the Bank Guarantee Fund outlined in it. Introduced in 2013 into the Credit Union Act, the legal architecture of a take-over of a credit union or its selected rights and liabilities by another credit union or bank following a decision of the Polish Financial Supervision Authority (the main legal form of credit union restructuring), derives from the legislation on (orderly) resolution, developed at the European level and implemented into the Polish legal system by means of the BGF Act, in 2016. In carrying out this transformation, the Polish legislator decided to apply the legal institution of resolution to the country's credit unions even though the latter are exempt from the implemented Directive establishing a framework for the recovery and resolution of credit institutions and investment firms. An analysis of the compared pieces of legislation leads to the conclusion that the power to decide on a take-over of a credit union or its selected rights and liabilities by another credit union or bank, granted to the Polish Financial Supervision Authority 
by the legislator, makes it always possible to PFSA, with regard to credit unions, to achieve the objectives of orderly resolution through the use of that very supervisory measure. The irreversibility of the decision, which can be appealed against only under a special procedure highly limiting the applicants' rights, and its financial consequences including the allocation of the acquired entity's own funds for covering losses, all that gives the decision the air of the decisions made in the context of the orderly resolution process. Meanwhile, the BGF Act provides that resolution instruments may only be applied only if the intended objective cannot be achieved by means of supervisory measures. Such a situation casts doubts, even in theoretical terms, as to the applicability of resolution instruments to credit unions. The doubts are further exacerbated by practical experience. The latter shows that BFG transferred funds to support credit union restructuring as early as in 2014, under the government's credit union orderly resolution programme accepted by successive decisions of the European Commission, precisely in the cases where the Polish Financial Supervision Authority decided on credit unions' take-over by banks pursuant to Article $74 \mathrm{c}$ of the Credit Union Act.

Key words: cooperative savings and credit union; bank, resolution; takeover; supervision; Bank Guarantee Fund

\section{BIBLIOGRAFIA}

Duda D., Przejęcie spółdzielczej kasy oszczędnościowo-kredytowej na podstawie decyzji administracyjnej Komisji Nadzoru Finansowego, „Prawo i Więź" 2018, nr 23, s. 50-61.

https://www.bfg.pl/przymusowa-restrukturyzacja/przymusowa-restrukturyzacja-w-pytaniach-i-odpowiedziach/(dostęp: 03.03.2021 r.).

Kłopoty PBS Banku. Podkarpacie przeciera oczy ze zdumienia, klienci licza utracone miliony, https://spidersweb.pl/bizblog/pbs-sanok-bfg-restrukturyzacja/ (dostęp: 03.03.2021 r.).

Medyński M., w: Ustawa o bankowym Funduszu Gwarancyjnym, systemie gwarantowania depozytów oraz przymusowej restrukturyzacji. Komentarz, red. P. Zawadzka, P. Zimmerman, R. Sura, Warszawa 2017.

Medyński M. i Zimmermann P., Ustawa o Bankowym Funduszu Gwarancyjnym, systemie gwarantowania depozytów oraz przymusowej restrukturyzacji - wielkie zmiany i ich przyczyny, „Monitor Prawa Bankowego” 2017, nr 2, s. 96-108.

Mędrzecka J., Łączenie się spółdzielczych kas oszczędnościowo-kredytowych a restrukturyzacja i uporzadkowana restrukturyzacja kas, w: Prawo 
prywatne $w$ służbie społeczeństwu. Księga poświęcona pamięci Profesora Adama Jedlińskiego, red. P. Zakrzewski, D. Bierecki, Sopot 2019, s. $187-201$.

Obligacje ryzykowne jak akcje. Po PBS $w$ Sanoku kolejne resolution jest tylko kwestią czasu, https: / /www.stockwatch.pl/wiadomosci/obligacjeryzykowne-jak-akcje-po-pbs-w-sanoku-kolejne-resolution-jest-tylkokwestia-czasu,obligacje,254646, (dostęp: 03.03.2021 r.).

Pelc P., Nadzór Komisji Nadzoru Finansowego nad spółdzielczymi kasami oszczędnościowo-kredytowymi a nadzór nad otwartymi funduszami emerytalnymi, w: Prawo prywatne w służbie społeczeństwu. Księga poświęcona pamięci Profesora Adama Jedlińskiego, red. P. Zakrzewski, D. Bierecki, Sopot 2019, s. 235-262.

Piłat W., Nowe procedury przymusowej restrukturyzacji $i$ uporzadkowanej likwidacji instytucji bankowych (resolution regime), „Doradca Restrukturyzacyjny" 2016, nr 3, s. 128-146.

Skoczek J., Kilka uwag o rzadowym projekcie ustawy o Bankowym Funduszu Gwarancyjnym, uporządkowanej likwidacji banków oraz zmianie niektórych innych ustaw z dnia 23 kwietnia 2013 roku, „Pieniądze i Więź” 2013, nr 2, s. 113-117.

Torończak M., Przejęcie banku - zagadnienia wybrane, „Monitor Prawa Bankowego" 2019, nr 4, s. 64-80.

Zakrzewski P., w: A. Herbet, S. Pawłowski, P. Zakrzewski, Spółdzielcze kasy oszczędnościowo-kredytowe. Komentarz, Warszawa 2014. 